\title{
Comparative Perspectives on the Regulation OF ASSISTED REPRODUCTIVE TECHNOLOGIES IN THE UNITED KINGDOM AND CANADA
}

\author{
ERIN L. NELSON*
}

This article highlights some concerns with the regulatory sinicture envisioned by Canada's new Assisted Human Reproduction Act, principally by compuring Canada's proposed Assisted Human Reproduction Agency (AHRA) with the United Kingdom's Human Fertilisation and Embryology' Authority (HFEA). The article elaborates on the past and present regulation of ARTs in both Canada and the Uniled Kingdom, using the current regulation of preimplantation genetic diagnosis by the HFEA as an example. The author notes that there is considerable cause for concern over the ability of the AHRA to effectively regulate ARTs, and countions that Canado 's proposed regulatory structure may serve only to reignite the debate around the moral status of the embryo that featured so prominently in the debate over the legislation itself.
Cet article fait ressortir quelques-unes des prioccupations retatives a la structure reglementaire envisagée par la nouvelle Loi sur la procrbation assistce du Conada, principalement en comparam le projet de Assisted Human Reproduction Agency (AHRA) du Canoda avec la Human Fertilisation and Embryology Authority' (HFEA) du Royaume-Uni. $L$ article decrit la réglementation passée et présente de la procréation assisté an Canada et au Royaume-Uni en utilisant la réglementation en vigueur sur le diagnostic génétique préimplantatoire de la HFEA di titre d'exemple. L. 'antur fait remarquer qu'il y a lien do se préoccuper de la capacifé de l'AHRA de regir efficacement ce domaine et met en garde que la structure réglementaire proposée du Canada pourrail seulement rounrir le débal aurour de l'érat moral de lembronon qui a èté all cuur du débat entouran la legislation.

\section{TABLE OF CONTENTS}

I. INTRODUCTION . . . . . . . . . . . . . . . . . . . . . 1024

1I. BACKGROUND/HISTORY ..................... 1025

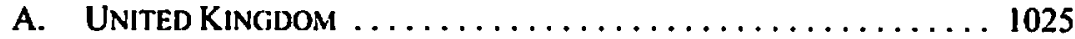

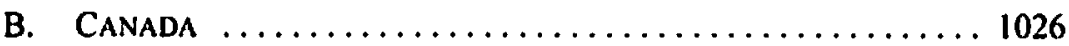

III. REgulating AsSisted REPRoductive TECHNOLOGIES . . . . . . . . 1028

A. UNITED KINGDOM $\ldots \ldots \ldots \ldots \ldots \ldots \ldots \ldots \ldots \ldots \ldots \ldots \ldots \ldots$

B. Canada ............................... 1029

IV. REgulation of Preimplantation Genetic Diagnosis . . . . . . . 1038

A. UNITED KINGDOM ....................... 1039

B. CanAda .......................... 1045

V. CONCLUSION ......................... 1047

Assistant Professor, Faculty of Law and Research Associate, Health Law Institute, University of Alberta. The author would like to thank Tania Bubela and the anonymous peer reviewers for their helpful comments on carlier drafls of this article, and Fiona Moore for her able teditorial assistance. In addition, the author would like to acknowledge the work of Tímothy Caulfield and Tania Bubela who, with the financial assistance of the StemCell Network, have created a database of the Parliamentary debates on issues related to stem cell rescarch and assisted reproductive technologies. 


\section{INTRODUCTION}

Since the government first introduced legislation to govern reproductive and genetic technologies, critics from all segments of society have been eager to express their views on its various flaws. To date, however, the criticism has by and large been aimed at the prohibitions enshrined in the statute. Until now, most of the critical commentary has been focused on what the rules should be, as opposed to how the rules should be made. Less has been said about the regulatory aspects of the legislation, likely because the structure the government has envisioned is only now becoming clear. Unfortunately, as the government's vision for the composition and role of the Assisted Human Reproduction Agency of Canada (AHRA) becomes increasingly manifest, the outlook for meaningful, dynamic regulation of assisted reproductive technologies (ARTs) in this country becomes increasingly bleak.

Regulation of ARTs need not entail tightly restricted access to such technologies, nor need it signify exceptional restraints on research into the technologies. To a significant degree, one's views on the utility of or need for regulation in this area depends on one's views of the potential harms that may arise from use of and research into these technologies unimpeded by regulatory controls, ' and one's faith in the policy making process involved in regulating. Even those who are pessimistic about the likelihood of effective state regulation of ARTs because of their lack of confidence in the political process would likely agree that the potential harms justify some level of scrutiny over the practices and procedures involved. ${ }^{2}$ I consider myself to be an optimist in terms of the possibilities for meaningful state regulation of ART research and practice. Yet, in spite of my optimism, I find considerable cause for concern in the vision of the regulatory agency put forward in Canada's new Assisted Human Reproduction Act. ${ }^{3}$

The AHRA tinds its closest counterpart in the United Kingdom's Human Fertilisation and Embryology Authority (HFEA). Although many countries have taken steps toward regulating at least some aspects of ARTs, ${ }^{4}$ the U.K. is the only one to have undertaken a virtually

1 Emily Jackson, for example, argues that "[u]nregulated reproduclion would unquestionably not be the best way to enhanec reproductive freedom." In her view, absence of exicmal constraints in the context of reproductive decision making does not adequately protect reproductive freedom (Emily Jackson, Regulating Reproduction: Law; Techmologl' and Aufonomy' (Oxford: Hart Publishing, 2001) at 318 [Jackson, Regulating Reproduction]).

2 Even John Robertson, probably the best known advocatc of a minimal state regulatory presenee in the area of reproductive regulation, does not advocate complete absence of regulation: sece e.g., John A. Robertson, "Procreative Liberty in the Era of Genomics" (2003) 29 Am. J. L. \& Med. 439 [Robertson, "Procreative Liberty"].

S.C. 2004, c. 2 [AHR Act].

For a bricf overview of steps taken internationally, see llealth Canada online: <www.hc-sc.gc.ca/hlvs/reprod/he-sc/general/intemational_c.html>; see also Bartha M. Knoppers \& Rosario M. Isasi. "Regulatory approaches to reproductive genetic lesting" (2004) 19 Human Reproduction 2695; Shaun D. Pattinson \& Timothy Caulfield. "Variations and voids: the regulation of human cloning around the world" (2004) 5 BMC Medical Eithics, online: BioMed Central <www.biomedcentral.com content/pdf/1472-6939-5-9.pdf\$; John A. Robertson, "Protecting embryos and burdening women: assisted reproduction in Italy" (2004) 19 Human Reproduction 1693; Joseph G. Schenker, "Assisled reproduction practice in Europe: legal and ethical aspects" (1997) 3 Human Reproduction Update 173; Sozos J. Fasouliotis \& Joseph G. Schenker, "Sociul aspeets in assisted reproduction" (1999) 5 Human Reproduction Update 26 at 26-27. 
comprehensive ${ }^{s}$ approach to ART regulation, and it has done so using an arm's-length agency similar to Canada's contemplated AHRA. The HFEA provides a helpful reference point not only because the two schemes are similar in scope and ambition, but also because the U.K. and Canada have similar parliamentary systems and have undertaken parallel public consultation processes in respect of ART regulation. ${ }^{6}$ Moreover, the HFEA has been in place since August 1991, as a result of the enactment of the Human Fertilisation and Embryology $A c t,{ }^{7}$ and provides a useful benchmark in terms of the evolution of the regulatory process.

In this article I attempt to elucidate the major problems with the proposed structure and function of the AHRA as imagined in the $A H R A C t$, principally by comparing the AHRA with the HFEA. In Part II of the article, I elaborate on the background and history leading to regulation of ARTs in both the U.K. and Canada. In Part III, I consider current regulation of ARTs in both countries, and in Part IV, 1 look at preimplantation genetic diagnosis (PGD) as an example of a technology that is regulated in the U.K. (and that will be regulated in Canada), in order to illustrate the detail-oriented nature of regulation in this field, and to note the controversies that have arisen in relation to PGD. Finally, I conclude by noting that Canada's proposed regulatory structure may do little more than breathe new life into the debate around issues relating to the moral status of the embryo that have been repeatedly debated since reproductive technologies first came on the scene.

\section{BACKGROUND/HISTORY}

\section{A. UNITED KINGDOM}

The U.K. has been a pioneer in the reproductive technologies context, starting with the birth of Louise Brown (the first child conceived and born using in virro fertilization (IVF)) in $1978,{ }^{8}$ and including the introduction of PGD. ${ }^{9}$ The U.K. has also been a leader when it comes to regulating reproductive (and genetic) technologies, from creating the Warnock Committe $^{10}$ to study the issues raised by emerging reproductive technologies, to the comprehensive regulatory legislation in place today.

Louise Brown's birth generated a flurry of government activity in the form of commissions to study the legal, ethical and social issues arising out of the use of assisted reproductive technologies." In the U.K., the government established a Committee of Inquiry

As Emily Jackson notes, not all assisted conception is regulated by the HFEA, such as self-insemination with fresh spern and gamete intra-fallopian transfer (GIFT). Sce Jackson, Regulating Reprochuction, supra note 1 at $184-85$. Technologies in Canada. See infra notes 10, 11.

(U.K.) 1990, c. 37 [IIFE Act].

" P.C. Steptoc \& R.G. Edwards, Letter to the Editor, "Birth after the reimplantation of a human cmbryo" (1978) 312 Lancet 366.

- A.H. Handyside el al., "Biopsy of human pruimplantation embryos and sexing by DNA amplification" (18 February 1989) 333 Lancet 347.

10 U.K., H.C., "Report Of The Committee Of Inquiry Inıo Human Fertilisation And Embryology," Cmnd 9314, 1984 [Wamock Committec].

1 Sce, e.g., Warnock Committee, ibid.; Royal Commission on New Reproductive Technologies, Proceed with Care: Final Report of the Royal Commission on New Reproductive Technologies. 2 vols. (Ottawa: Minister of Govemment Services Canada, 1993) |Proceed with Care]: Ontario Law Reform 
into Human Fertilisation and Embryology (the Warnock Committee), which recommended in 1984, inter alia, legislation governing clinical and research applications of assisted reproductive technologies, and the establishment of a statutory authority - the HFEA. In March 1985, a Voluntary Licensing Authority (VLA) was created by the Medical Research Council and the Royal College of Obstetricians and Gynaecologists. ${ }^{12}$ In 1987, the British government published a White Paper outlining its plans to introduce legislation in the area. ${ }^{13}$ Two years later, the VLA changed its name to the Interim Licensing Authority for Human In Vitro Fertilisation and Embryology, to better reflect its temporary status. Finally, in 1990. the HFE ACl ${ }^{\text {is }}$ was passed by both Houses of Parliament and received Royal Assent, and the HFEA became fully operational in August 1991.

\section{B. Canada}

The Canadian response to the burgeoning science of assisted reproduction has paralleled that of the U.K. In 1989, the Canadian government established the Royal Commission on

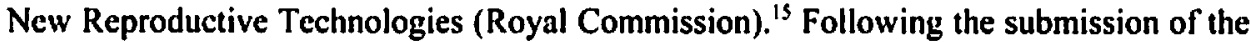
Royal Commission's report in 1993, ${ }^{16}$ a voluntary moratorium was instituted to address some of the Royal Commission's recommendations ${ }^{17}$ and, in 1996, an advisory committee was established to help monitor compliance with the moratorium. Later in 1996, the government introduced Bill C-47, the Human Reproductive and Genetic Technologies Act. ${ }^{18}$ The Bill was

Commission, Report on /human Artificial Reproduction and Related Matters, 2 vols. (Toronto: Ontario Law Reform Commission. 1985); Law Reform Commission of Canada. Medically assisted procreation (Working Paper 65) (Ottuwa: Minister of Supply and Services Canada, 1992); Family Law Council, Creating Children: A Uniform Approach to the Law and Practice of Reproductive Technology in Australia (Canberra: Australian Government Publishing Service, 1985); Committee to Consider the Social, Ethical and Legal Issues Arising from In-vitro Fertilisation, Consolidated Reporis of the Victorian Inquiry into IVF and Related Issues by Louis Waller (Melboume: Victorian Government Printer, 1990); Sclect Commiltet of the Legislative Council, Artificial Insemination by Donor, In-Vitro Fertilisation and Embryo Tramsfer Procedures and Related Matters in South Australia (Adelaide: South Australian Government Printer, 1987); New South Wales Law Reform Commission, Report: Artificial Conception - Human Arificial insemination (Sydncy: South Australian Govemment Printer. 1986); New South Wales Law Reform Commission, Report, Artificial Conception - In Vitro Fertilisation (Sydney: New South Wales Government Printer, 1988); New South Wales Law Reform Commission. Report - Arificial Conception - Surrogate Motherhood (Sydncy: New South Wales Government Printer, 1988).

U.K., H.C., Science and Technology Committee, Human Reproductive Technologies and the Law Fifth Report of Session 2004-05, 2 vols. (London: The Stationery Office, 2005) at 7-8 [Human Reproductive Technologies and the Lawl.

U.K., H.C., White Paper: Human Ferrilisution and Embryology: A Framework for Legistation, Cm 259. 1987. Supra note 7.

The Ontario Law Reform Commission and the Law Reform Commission of Canada also studied reproductive and genetic technologits (ste supra note 11).

16 Proceed with Care, supra nute 11.

"Such as sex selection for non-medical purposes, purchase and sale of gametes and embryos, commercial surrogacy, germ-line genetic alteration, human cloning and the creation of animal-human hybrids. See Health Canada, New Reproductive and Genetic Technologies: Selting Boundaries, Enhancing Heallh (Ottawa: Minister of Supply and Services, 1996) at 7 [Setting Boundaries, Enhancing Healh]. 
heavily criticized for its focus on criminal prohibitions. ${ }^{11}$ Bill C-47 died on the Order Paper when Parliament was dissolved for an election in the spring of 1997. At the same time as the introduction of Bill C-47, the federal government published a report entitled: New Reproductive and Genetic Technologies: Setting Boundaries, Enhancing Health, in which plans for the creation of a regulatory framework were detailed ${ }^{20}$ Here, too, strong criticisms were raised around the need for and legitimacy of federal (as opposed to provincial) regulation of reproductive technologies. ${ }^{21}$ After this initial activity to follow-up on the Royal Commission's recommendations, the government retreated somewhat from policy making in this area.

In 2000, however, Health Canada began a consultation process in which stakeholders and representatives from provincial and territorial govemments were canvassed as to their views on the best way forward. In 2001, then Minister of Health Allan Rock presented draft legislation to the House of Commons Standing Committee on Health. The Committee reviewed the legislation and issued its own report and recommendations in December $2001 .^{22}$ Bill C-56, the Assisted Human Reproduction Act was introduced into the House of Commons in 2002; ${ }^{23}$ the Bill was passed by both the House of Commons and the Senate, and received Royal Assent on 29 March 2004.4 As of 22 April 2004, a number of sections have come into force (primarily those dealing with controlled and prohibited activities). ${ }^{25}$

The legislation contains both prohibitory and regulatory aspects. The $A C t$ describes a number of "prohibited" activities and sets out penalties for engaging in such activities, and it also institutes a regulatory scheme, including the creation of a regulatory agency (the AHRA). The regulatory system will operate in a fashion at least somewhat similar to that in the U.K., in that it will function as a licensing scheme overseen by a central authority that is independent of government. The objectives of the AHRA are to "protect and promote the

See Alison Harvison Young \& Angela Wasunna, "Wrestling with the Limits of Law: Regulating New Reproductive Technologies" (1998) 6 Health L. J. 239; Patrick Healy, "Statutory Prohibitions and the Regulation of New Reproductive Technologies under Federal Law in Canada" (1995) 40 MeGill L.J. 905; and Timothy Caulfield, Marie Hirtle \& Sonia LeBris, "NRGTs: Is Criminalization the Solution for Canada?" (1997) 18 Health L. Can. 3. Supra note 17.

21 See Harvison Young \& Wasunna, supra note 19 and Ilealy. supra note 19. The criticisıms around federal regulatory involvement in this area were premised on the fact that "health" is generally viewed as a provincial, rather than federal, constilutional responsibility.

House of Commons Standing Committee on Health, Assisted Human Reproduction: Building Families (Ottawa: Standing Committee on Health, 2001), online: <www.parl.gc.ca/InfoComDoc/37/1/HEAL Studies/Reports/healrp01/03-cov-e.htm> [Building Families].

24 Finally, after 11 years of debate, discussion and failed attempts at legislating. See for example: Timothy Caulfield, "Bill C-13: The Assisfed lluman Reproduction Act: Fxamining the Arguments Against a Regulalory Approach" (2002) 11:1 Health L. Rev. 20 [Caulficld. "Bill C-13"]: Timothy Caulfield, "Clones, Controversy and Criminal Law: A Comment on the Proposal for Legislation Governing Assisted Human Reproduction" (2001) 39 Alta. L. Rev. 335 [Caulfield, "Clones. Controversy and Criminal Law"]: Harvison Young \& Wasunna, supra note 19; Françoise Baylis, "Human Cloning: Three Mistakes and an Altemative" (2002) 27 Journal of Medicine \& Philosophy 319.

See Health Canada, "A Chronology of the Assisted Human Reproduction Act," online: Health Canada <www.hc-sc.gc.ea/hl-vs/reprod/hc-sc/general/chronolog_c.html>. In addition, ss. 21-39 and 72, 74, 75 and 77 came into force in January 2006 . The majority of the $A c t$ will come into foree on a date to be specified by order of the Govemor-in-Council. 
health and safety and privacy of Canadians in relation to Assisted Human Reproduction" and to "foster the application of ethical principles" to ART-related issues. ${ }^{26}$

\section{Regulating ASSISTED RePROductive TeChNOLOGIES}

\section{A. UNITED KINGDOM}

In the U.K., clinical and research uses of assisted reproductive technologies, and embryo research generally, are comprehensively regulated under the HFE Act. ${ }^{27}$ The HFE ACt establishes a permissive licensing scheme whereby a central non-governmental body - the HFEA - is established and delegated authority to license and monitor facilities that perform reproductive technologies and related research, including IVF, donor insemination and human embryo research. The $A c t$ assigns the HFEA the power to grant licences to facilities that wish to carry out such work, upon application by the facilities. In general, the HFEA may grant licences for any conceivable application of reproductive technologies, except those that are specifically prohibited by the legislation (for example, research involving the use of embryos "older" than 14 days. ${ }^{2 *}$ placing non-human gametes or embryos in a woman ${ }^{29}$ and embryo cloning by nuclear substitution ${ }^{30}$ ). As noted above, it was the view of the Warnock Committee that regulatory oversight of ARTs and embryo research was required to protect the public, and that the regulatory function should be played by an expert body, independent of government. To that end, the Warnock Committee recommended the creation of a statutory licensing authority to regulate both research and clinical activity in this area. ${ }^{31}$

The Committee recognized the need for medical and scientific expertise in the membership of the authority but also explicitly advocated for substantial lay representation, including the recommendation that the chair of the board must be a layperson. ${ }^{32}$ Although not formally included in its "recommendations," the Committee also elaborated on its vision of the mandate of the recommended statutory authority, which included both advisory and executive functions. The executive function of the authority related to licensing of ART treatment, as well as research involving human gametes and embryos. ${ }^{33}$ The authority's advisory role, as envisaged by the Committee, extended to the issuing of guidelines respecting good practice "in infertility service provision and on the types of research which, without prejudice to its view of any individual project, it finds broadly ethically acceptable." $^{34}$

AHR Act, supra note 3, s. 22

Supra note 7.

Ibid., ss. 3(3)(a), 3(4).

Ibid., s. 3(2).

Ibid., s. 3(3)(d). The prohibition on cloning by nuciear substitution applies only to embryos; eggs may be cloned for researcli purposes. The HFE Act also grants the Secretary of State for Health the power to make regulations respecting clanges to the prohibitions or mandatory conditions for licences, but only if such regulations are laid before and approved by both Houses of Parliament in dran form (s. 45(4)). Mary Warnock, A Question of Life: The Warnock Report on Human Ferrilisation and Embryology (Oxford: Basil Blackwell, 1985) at para. 13.3 [Warnock Report]. 
The recommendation respecting the advisory function of the authority translated into, in part, s. 25 of the HFE Act, which requires the HFEA to maintain a Code of Practice "giving guidance about the proper conduct of activities carried on in pursuit of a licence under this Act.. ${ }^{35}$ The Code of Practice is to be approved by the Secretary of State for Health, after which it is to be laid before Parliament. ${ }^{36}$ The Code of Practice, now in its sixth iteration, ${ }^{37}$ provides detailed guidance regarding the following: qualifications and responsibilities of staff employed by licensed centres; facilities and administrative procedures for licensed centres; assessments of the "welfare of the child",3k and of persons secking treatment; assessment and screening of potential gamete donors; provision of information to donors and to service recipients; consent; counselling; use, storage and handling of gametes and embryos; research; records and confidentiality; complaints; preimplantation testing; witnessing clinical and laboratory procedures; and intra-cytoplasmic sperm injection.

\section{B. Canada}

Once it is in place, the AHRA, like the HFEA, will have the power to issue, suspend, renew, amend and revoke licences for treatments or research involving AHR techniques; ${ }^{39}$ inspect clinics and labs to ensure health and safety; ${ }^{\text {t0 }}$ maintain confidential personal health information pertaining to donors, patients and offspring born of AHR procedures; ${ }^{41}$ advise the Minister of Health and to monitor national and international policy developments; ${ }^{42}$ and provide information to the public on the operations of the agency and ART issues, including public reports on outcomes. ${ }^{43}$

Canada's Royal Commission took a view similar to that of the Warnock Committee with regard to effective regulation of reproductive technologies; as Rebecca Cook and Bernard

HFE Acl, supra note 7.

Ibid., s. 26 (for purposes of information and formal publication). The $A C t$ also specifies that if the Secretary of State does not approve the Code of Practice, he is to provide reasons to the Authority (s. 26(3)).

Human Fertilisation and Embryology Authority, Code of Practice, 6th ed. (London: HFEA, 2003), online: HFEA <www.hfea.gov.uk/HFEAPublications/CodeolPractice/Code $\% 20$ of\%20Practice $\% 20$ Sixth\%20Edition\%20-\%20final.pdf $>$ [Code of Practice].

Section 13(5) of the HFE ACt, supra note 7, requires trealment providers to take account "of the welfare of any child who may be born as a result of the treatment" prior to the provision of services. Section 25(2) requires that guidanee on this issue be included in the Code of Practice. The HFEA conducted a review of its guidance on this issue, including conducting a public consultation to assist in its review. See Human Ferilisation and Embryology Authority, Tomorrow' s children: A consultation on guidance to licensed fertility clinics on taking in account the welfare of children to be born of assisted conception treatment (London: HFEA, 2005), online: HFEA <www.hfea.gov.uk/AboutHFEA/ Consultations/Welfare\%20 $\%$ \%20the\%20child\%20Tomorrows\%20Children.pdf>. The report, Tomorrow' 's children: Report of the policy review of welfare of the child assessments in /icensed assisted conception clinics, was released by the HFEA in November 2005, online: HFEA <www. hfea.gov.uk/A boutHFEA/HFEAPolicy/TomorrowsChildren-ReviewoftheHFEAguidance on WelfareofheChild/TomorrowsChildren.pd $>$ This issue is al so likely to be a focal point of an ongoing government review of the IIFE ACI, see infra note 77.

AlIR Act, supra note 3, ss. 40-42.

Ibid., ss. 24(1)(g) and 45-47.

Ibid., s. 24(1)(e).

lbid., ss. 24(1)(b), (c).

lbid, s. 24(I)(f). 
Dickens have noted, the Royal Commission was impressed by the British regulatory model..$^{\text {44 }}$ The Royal Commission had additional issues to contend with, given Canada's federal system and the constitutional division of powers, ${ }^{45}$ but was committed to a federal regulatory presence in the ART context. The demand for national oversight was based on the views expressed to the Royal Commission by witnesses, as well as on the results of the research carried out by the Royal Commission. ${ }^{\text {th }}$ In addition, the Commissioners themselves took the view that "a field with such wide-reaching social, ethical, and public policy implications could never be dealt with adequately by a single government ministry or department,"N7 and that the best way toward resolution of these issues was founded in a national response. ${ }^{4 k}$

As noted earlier, the $A H R A C l$ contemplates the establishment of the AHRA. This agency was envisioned by the Royal Commission as a national regulatory agency with a mandate to deal with the following major functions: "licensing and monitoring; guideline and standard setting; information collection, evaluation, and dissemination; records storage; consultation, coordination, and intergovernmental cooperation; and monitoring of future technologies and practices." as an essential component of the regulator's licensing function, and as comprising responsibility for "developing national guidelines and standards of practice applicable to the development and delivery" of ARTs. ${ }^{\text {s0 }}$ The Royal Commission also recognized that the guidelines and standards developed by the agency would be of use to health care providers even in relation to matters not subject to the licensing regime. ${ }^{\$ 1}$

In its 1996 report Setting Boundaries, Enhancing Health, ${ }^{52}$ Health Canada stated that one of the "major functions" of the regulatory agency "would include the development of national standards for the uses of reproductive materials in medical research and practice." $\$ 3$ The report indicates that the standards would be subject to the Minister's approval, but it seems to have been the intention that they would be developed by the regulatory agency, not by the Minister or the department. ${ }^{54}$ While the Standing Committee on Health, in its 2001 report, agreed in principle with the idea of a regulatory agency existing outside of Health Canada, the Committee took a very different view of the role of this agency than the Royal Commission and Health Canada. The Committee describes the agency as a "semi-

B.M. Dickens \& R.J. Cook. "Some cthical and legal issues in assisted reproductive technology" (1999) 66 International Journal of Gynaecology \& Obstetrics 55 at 57.

The constitutional issues will not be discussed in detail here. For consideration of these issues, set Proceed wish Core, supra note II at 15-22; Harvison Young \& Wasunna, supra note 19; and Healy, supra note 19.

Sec Proceed with Care, ibid al 11.

Ibid. at 13.

Ibid. at $1-22$.

Ibid. at $115-16$.

Bbid. at 117.

Ibid. at 118.

Sitpra note 17.

Ibid. at 30.

Although, in the "draft" legislation referted to by the House of Commons Standing Committee on \& lealth in 2001, there is no mention of an independent regulatory authorily; instead, the administrative functions that the AHRA will fulfill are all described as being performed by the Minister of Health. Health Canada, "Draft: Proposals for legislation governing assisted human reproduction," copy on file with author, online: Health Canada <www.he-sc.gc.ca/ahc-asc/alt_formats/cmed-dcmc/pdf/media/ releasescommuniques $/ 2001 /$ egislation.pdf $>$. 
independent body"ss that reports to the Minister of Health. Further, the Committee felt that the Minister's role would include responsibility for "reproductive and genetic technology policies ...; [and] the overall direction of the regulatory body."

The Committee's view on the respective roles of the Minister of Health and the agency translated into quite a different approach than that adopted in the HFE Act. ${ }^{57}$ In contrast to the $H F E A c t$, which (as noted above) explicitly requires the HFEA to develop and maintain a Code of Practice, the $A H R A c t$ contains no such provision. The closest the $A c t$ comes to any mention of practice standards is found in s. 24(1)(f), which provides:

24(1) The Agency may ...

(f) provide information to the public and to the professions respecting assisted human reproduction and other matters to which this Act applies, and their regulation under this Act, and respecting risk factors associated with infertility. ${ }^{58}$

Rather than leave the details of the licensing regime and associated functions to the AHRA, the $A c t$ contemplates that these matters will be dealt with in regulations. Section 65 sets out regulation making powers in relation to, inter alia, the terms and conditions of licences, ${ }^{54}$ the qualifications for licences or controlled activities, ${ }^{60}$ the "issuance, amendment, renewal, suspension, restoration and revocation of licences," respect of applications for a licence (or renewal), ${ }^{62}$ counselling services, ${ }^{63}$ and the provision of information for purposes of informed consent to donation of gametes or provision of health information to a licensee. ${ }^{64}$ It is clear that the content of the regulations will be determined by the Minister, who is permitted to "issue policy directions to the Agency concerning the exercise of any of its powers."

The $A H R$ Act having only been passed in March 2004, the regulation making process has only begun. In November 2004, Health Canada (through the Assisted Human Reproduction Implementation Office, or AHRIO) announced the commencement of the process of developing the "regulatory components" of the Act which, it is anticipated, will take place over a three-year period. ${ }^{66}$ According to AHRIO, public consultation will feature prominently in the development of the regulatory framework, apparently in respect of all aspects of regulation, including the structure and administration of the licensing regime. Public consultation is often a part of the regulation making process and is explicitly contemplated

Building Families, supra note 22 at 25.

Ibid. at 26 (Recommendation 24).

Supra note 7.

AHR Act, supra note 3, s. 24(1)(f). See also s. 24(I)(b), which states that the Agency may "provide advice to the Minister on assisted human reproduction and other matters to which this Act applies."

Jbid., s. 65(I)(h).

Ibid., s. 65(1)(j).

Jbid., s. $65(1)(k)$.

Jbid., s. 65(1)(1).

Jbid., s. 65(1)(p); see also s. 14(2)(b).

Jbid., s. 65(1)(q); see also s. 14(2)(d).

Ibid., s. 25(1).

See Health Canada, online: <www.hc-sc.gc.ca/ach-ase/media/nr-cp/2004/2004_54_e.html>. 
in the Government of Canada's Federal Regulatory Policy, ${ }^{67}$ a ten-step process that normally concludes with review of the proposed regulations by the Standing Joint Committee for the Scrutiny of Regulations, whose role is to "[monitor] the exercise of regulatory power on behalf of Parliament. ${ }^{168}$ The regulation making process under the $A H R A C l$, however, does not end there. Rather, the $A c$ requires the extraordinary step of laying proposed regulations before both Houses of Parliament, for review and reporting by the appropriate committee(s) of each House. ${ }^{69}$

The delineation of the Agency's role in the $A H R A C t$ is disappointing for two main reasons. First, the policy making role is granted to Health Canada, rather than to the expert AHRA. The complete absence of any policy making or standard-setting role for the AHRA seems misguided in that it fails to recognize one of the major reasons for and benefits of the creation of the AHRA - the creation of an expert body with an important role to play in setting the standards that relate to the clinical and research applications of ARTs under its authority. ${ }^{70}$ Arguably, the $\mathrm{ACt}$ permits the possibility of "dialogue" between the AHRA and

See Canada, Privy Council OMice (PCO), Regulatory Process Guide: Developing a Regulatony Proposal and Seeking its Approvol, online: PCO <www.pco-bep.gc.ca/raoics-srdc/default.asp?Language= E\&Page=Publications\&doc=regguide/regguide_e.htm\#introduction>. Jbid. at step 10.

69 AHR Act, supra note 3, s. 66(1). The only situations in which this extraordinary process does not have to be followed are ( $i$ ) where the Minister considers the changes to an existing regulation so "immaterial or insubstantial" that the requirement should not apply, or (ii) where the regulation must be made immediately to protect health or safety (see s. $67(1)$ ). This process was the result of Recommendation 18 in Building Families, stupra note 22 at 19. The Committee was concemed about the "broad and largely unfettered regulation making power of the Govemor in Council" and therefore recommended that the Minister be required to place proposed regulations before the appropriate Parliamentary committees. A similar regulation making process is found in the robacco Act, S.C. 1997, c. 13, s. 42.1. The record of the debate in the House of Commons on this issue illustrates that the primary reasons for requiring this process were the following: the grant of a very broad regulation making power in the legislation, the fact that aspects of the former statute had recently been declared unconstitutional by the Supreme Court of Canada (in RJR-MacDonald Inc. v. Canada (Allorney General), [1995] 3 S.C.R. 199), and the hope that a more public regulatory process would permit stakeholders to have their say which would, in turn, reduce the likelihood of future legal challenges to the statute. These reasons speak to the fact, in part at least, that the regulation making function under the Tobacco $\mathrm{ACl}$ is exereised by the Minister of Health, and that the entity responsible for both crafting the regulations and applying them is the department.

70 The Royal Commission envisioned an entity made up of "persons knowledgeable about the interests and perspectives of those with disabilities, those who are infertile, and those who are members of racial minority, Aboriginal, and ceonomically disadvantaged communities." In addition, the Royal Commission called for representation of expertise in law, ethics, reproductive medicine and the social seiences. The Royal Commission also recommended that "normally at least half" of the members of the regulatory body should be women. See Proceed with Care, supra note 11 at 122-23. The $A H R A C l$ specifies that "[t]he membership of the board of directors must reflect a range of backgrounds and disciplines relevant to the Agency's objectives" (s. 26(2)), but does not include any reference to the number of women to be on the Board of Directors, or even mention that having a significant number of women on the board would be desirable. The House of Commons Standing Committee on Health also recommended that "[ $[$ ] [omen comprise at least half of the Board's membership" (see Building Families, supra note 22 at 41 , Recommendation 27(e)), and this was a contentious matter during the Parliamentary debates around the $A I I R$ Act (sec e.g., 37th Parliament, 2d Sess., No. 047 (28 January 2003); No. 048 (29) January 2003); No. 057 (II February 2003) [House of Commons Debates]. Another recommendation made in Building Families respecting the composition of the Board of Directors did find its way into the legislation: s. 26(8) stipulutes that "[a] person is not eligible to be a member of the board of directors if they hold a licence or are an applicant for a licence or a director, officer, shareholder or partner of a licensee or applicant for a licence." This provision may well prove to be cause for concern in terms of 
the Minister of Health, through s. 24(1)(b), "but given other features of the legislation, including the fact that the Minister may provide policy directions to the Agency and that the Minister determines the content of the regulations (and the fact that the government seems to see the Agency as having no role in the policy process ${ }^{7}$ ), the prospects for a meaningful exchange seem remote. The second problem with the policy process is the nature and degree of Parliamentary oversight envisioned in the $A H R A C t$. As will be elaborated on below, there are other ways in which Parliament can maintain a significant role in the policy process without creating, as the $\mathrm{s} .66$ process does, the potential for delay and for renewed debate around the political issues that were decided with the passage of the $A C t$.

The concerns raised in Building Families, which have translated into the approach taken in the $A H R A c t$, reflect a fundamental tension in approaches to public decision making. ${ }^{73}$ Contemporary governments rely heavily on administrative agencies, which can range from being more or less independent from government, and which can play a wide variety of roles. ${ }^{74}$ Some such agencies, for example, are primarily adjudicative (for example, labour boards), while others exercise adjudicative and policy making functions (such as energy boards, the CRTC, and securities commissions). On the one hand, there are advantages to independent agencies, separate from but accountable to the executive and legislative branches of government, such as the ability to include experts in their membership, the fact that policy making can take place in a more responsive fashion, and the fact that these entities are "insulated against political pressures." The primary disadvantage of such institutions, from the point of view of those who advocate for more democratic decision making, is that the body is not elected and therefore not directly accountable to the public in the same way as Members of Parliament and Legislative Assemblies.

This tension comes across very plainly in a report recently tabled by the U.K. House of Commons Select Committee on Science and Technology. ${ }^{76}$ In October 2003, the Select

actually obtaining persons with sufficient expertise, particularly given Canada's relatively small community of fertility experts. While it is understandable that concerns about conflicts of interests would arise in this context, there are arguably better ways to manage such contlicts than by barting experts from involvement, such as public declarations of any such conflicts, and rules that prevent an individual board member from making licensing and/or enforcement decisions about a facility in which they have a financial or research interest.

11 Sec supra nole 58.

"At a "technical briefing" on the $A H R$ Acr held in Edmonton in November 2004, the representative of Health Canada indicated that the Department anticipates the Board of Directors of the AHRA will be in place up to two years before the regulation making process is complette (see Health Canada, online: <www.he-sc.gc.ca/hl-vs/reprod/hc-sc/public/index_e.html>). I asked the representative what the role of the Board of Directors will be in relation to the ongoing development of the regulatory components of the $\mathrm{ACt}$ and was told that the Board would have no role in the process.

i3 Although a detailed discussion of issues and concerns related to the various roles filled by administrative agencies generally is beyond the scope of this article, the issue of accountability does merit brief discussion.

Sec e.g. David J. Mullan, ed., Administrative Law: Cases, Texf, and Materials, Sth ed. (Toronto: Lmond Montgomery, 2003) at 13-14; Lorne Sossin. "Speaking Truth to Power? The Search for Bureaducratic Independence in Canada" (2005) 55 U.T.L.J. I at 53.

" Human Reproductive Technologies and the law, supra note 12 at 154.

io lbid. Whether this report will prove persuasive is an open question. Of the 11 members of the Select Committee, live expressed disagreement with the report (see House of Commons, Science and Technology Committee, Inquiny into Human Reproductive Technologies and the Law - Eighth Special Report of Session 2004-05 (London: The Stationery Office, 2005) [Eighth Report]). The dissenting 
Committee on Science and Technology embarked on a review of the legal regime in place with respect to reproductive technologies (in other words, the HFE $A c t$ and the HFEA), having apparently become frustrated with the Department of Health's failure to review the Act. ${ }^{7}$ The Select Committee presented its report in March 2005, calling for greater powers for Parliament "to debate and amend legislation," and arguing that "a larger role for our democratically accountable Parliament would give the public greater confidence that the big ethical issues of the day are being given adequate attention." 78

It seems fairly clear that what is desired by both advocates for arm's-length agencies and those who urge a greater role for Parliament is accountability, transparency and respect for public opinion. ${ }^{79}$ The disagreement primarily centres around how best to achieve those aims. ${ }^{30}$ While there are benefits and disadvantages to both systems, to my mind the benefits weigh in favour of an independent regulator, for a number of reasons. First, such an organization can make use of expertise by including in its membership individuals with knowledge of legal, ethical and medical issues - complex areas in which legislators (including those sitting on a particular committee) do not necessarily have specific knowledge.

Second, and perhaps most significant, an independent agency is able to be flexible and responsive in respect of new scientific developments. If the past few years in the Canadian ART context have taught us anything, it is that decision making by legislatures on these issues is not quick. It has been over 12 years since the Royal Commission submitted its final report and it has taken that long for Parliament to make any headway into the regulation of ARTs. Even at that, all we have achieved is a statute that is partly in force. Eleven years is a long time to wait for the enactment of legislation on any pressing issue, but it is particularly

members of the committee expressed reservalions on a number of fronts, including the refusal to re-draft the entire report after adoption of a significant amendment, the unseasonable restrictions on time given for consideration of amendments, and failure to give appropriate regard to the results of the public opinion submitted to the committee. Shortly after the reports were tabled, Parliament was dissolved for an election, so there is as yet no indication as to the importance with which this report will be viewed. Human Reproductive Technologies and the Law, ibid. at 3. The Department of Health has since launched its own review (Department of Health. News Release, "Review of the Human Fertilisation and Embryology Act 1990" (20 January 2004), online: Department of Health <www.dh.gov.uk/ PolicyAndGuidance/HealthAndSocialCareTopics/AssistedConception/AssistedConceptionGeneral Information/AssistedConceptionGeneralArticle//s/en?CONTENT_ID=4069149 \&chk=MSMizC $>$ ). Human Reproductive Technologies and the Law, ibid. at 186.

Sec for example: Building Families, supra note 22; Human Reproductive Technologies and the Law, ibid, vol. 2: Oral and Written Evidence, online: <www.publications.parliament.uk/pa/cm200405/ cmselect/cmsctech/7/7ii.pdf at Ev 84, Ev 95, Ev 215, Ev 221, Ev 242, Ev 246, Ev 272 [Human Reproductive Technologies and the Law, Oral and Written Evidence].

Of course, there are those who suggest that state regulation of ARTs itself is misguided (see e.g., John A. Robertson. Children of Choice: Freedom and the New Reproductive Technologies (Princeton: Princeton University Press, 1994); Robertson, "Procreative Liberty," supra note 2; Judith F. Daar. "Regulating Reproductive Technologies: Panacea or Paper Tiger?" (1997) 34 Houston L. Rev. 609), but I agree with Jackson on this point (see Regulating Reproduction, supra note 1). Complete deregulation of research and clinical practice in assisted reproductive technologies is not only not wise, it is not realistic. Because reproductive technologies cannot be accessed without professional assistance, there is inevitably a "gatekeeper" involved in the use of the technologies, whether that comprises individual physicians, professional organizations or the state itself. If regulation is left to individual physicians, or even professional organizations such as the ASRM, real concems about transparency and accountability arise. 
cause for concern in a rapidly evolving area of science that creates new technologies and associated ethical, social and legal issues at an astonishing pace. As Timothy Caulfield points out, in the time between the report of the Royal Commission and the proposed legislation that has ultimately become the $A H R A c t$, "[w]e have ... mapped the human genome, cloned a variety of mammals, developed new assisted reproductive technologies, and witnessed ground breaking advances in the area of stem cell research." ${ }^{\text {81 }}$ Even if concerns about timeliness of parliamentary process could be resolved, however, we must also consider how much parliamentary time we want to devote to this single issue, important as it may be. Given the evolving nature of the science behind assisted reproduction, we can expect change to be a constant in this field. Do we really want to address each and every such change through comprehensive parliamentary review? ${ }^{82}$

Third, it bears mention that being insulated against political pressures ${ }^{\mathbf{x}}$ in an area as sensitive and controversial as ART-related research and practice is a substantial benefit. Policy making in this area is fraught with difficulty, given the strong views held by various segments of sociely on embryonic life, ${ }^{\mathrm{s}}$ the propriety of embryo research and the acceptability of various genetic technologies in the assisted reproduction context. ${ }^{85}$ As can be seen by simply perusing the list of witnesses and stakeholders that have appeared before the Royal Commission and the various parliamentary bodies that have examined the issue since 1993, an enormous number and range of groups feel that they have an important stake in framing any decision making process that will govern applications of ARTs. These include religious groups, medical and other health professionals (and related voluntary associations), legal professionals, specific ethnic and national communities, and individuals and/or groups representing those affected by infertility or who desire access to specific technologies. Each of these groups has its own interests in and positions on various aspects of regulatory oversight, all of which demand respect and consideration. But at the end of the day, no matter where decision making takes place, some of these parties will be disappointed with decisions made, be they related to prohibited activities, permitted activities or licences to undertake specific research or practice in the clinical setting. ${ }^{86}$ Indeed, the very fact of the diverse

81 Caulfield, "Clones, Controversy and Criminal Law," supra note 24 at 338 [footnotes omitted].

82 This concerm seems especially germane in light of the current unstable national political climate.

3) See Mullan, supra note 74 at $16-17$.

s4 The conflict around which, as limily Jackson notes, is simply not amenable to consensus (Jackson. Regulating Reproduction, supra note ( at I).

See e.g., Timothy Caulfield, "Too heavy a hand on science" The Globe and Mail (3 June 2005) A2I, noting that the Parliamentary debates on the $A H R A C t$ were "dominated [by] political rhetoric on the moral status of the embryo"; House of Commons Debates, supra note 70, 047 (28 January 2003) at 2778 (Mr. Jason Kenney), 2811 (Mr. Chuck Strahi), 2816 (Mr. Ken Epp), 2819 (Mr.Jim Karygiannis); House of Commons Debates, 048 (29 January 2003) at 2858 (Mr. David Anderson), 2862-63 (Mrs. Elsie Wayne); House of Commons Debates, 049 (30 January 2003) at 2973 (Mr. Richard Harris), 2978 (Mr. Philip Mayficld), 2982 (Mr. Ken Epp); House of Commons Dethates, 053 (5 Fubruary 2003) at 3191 (Miss Deborah Grey). 3192 (Mrs. Elsie Wayne). 3196 (Mr. Leon Benoit); House of Commons Debates, 057 (11 February 2003) al 3399 (Mr. Réal Mènard), 3403 (Mr. Gerry Ritz), 3405 (Mr. Reed Elley); and Human Reproductive Technologies and the Law: Oral and Wriften Evidence, supra note 79 at Ev 113. 
interests and concerns raised by ARTs is a good reason for creating a regulatory body that is truly independent. The strongly held views of many segments of society will help to ensure that these issues remain very much in the public eye, which will further ease worries about decision making by unelected entities.

To be sure, there are legitimate concerns around the issue of democratic accountability, particularly given the significance of regulation of assisted reproduction research and practice and its potential ramifications for society. But while the reluctance to devolve decision making in this area to an unelected entity is understandable, most, if not all, of the concerns can be responded to. In short, simply creating an arm's-length body to make these important decisions need not mean that there will be no accountability. Compulsory public consultation, combined with a mandate to educate and inform the public about Agency business will ensure that decision making remains transparent. ${ }^{87}$ Further, it is possible to create an independent entity with some policy making role and with significant parliamentary oversight. As noted above, the $A H R A c t$ requires that regulations proposed by the Minister be put before both Houses of Parliament for review and approval. ${ }^{88}$ While this is not a desirable approach from the point of view of timely response to these issues, it is one possible approach through which significant parliamentary oversight can be provided. Another way to achieve this same end (without sacrificing as much in terms of flexibility and responsiveness) is through use of a "negative resolution process," which stipulates that regulations come into effect unless rejected by a resolution of the House of Commons and the Senate. ${ }^{89}$

The benefits of public regulation in the area of reproductive technologies include quality control, ${ }^{41}$ public knowledge, accountability and transparency of processes," as well as facilitation of the transition of various technologies from research to practice. Clearly, a number of these functions are beyond the scope of Health Canada (or any other government

Eimbrology Authority. [2005] 2 A.C. 561, 2005 UKHL 28 [Quintavalle, H.L.]; CORE, Press Reltase. "Lords Rule in Favour of Designer Babies ... Parliament Must Reclaim Authority" (28 April 2005), online: $C O R E<w w w . c u r e t h i c s . o r g /$ document.asp? id $=c p r 280405 . t x 1 \& s e=2 \& s t=6>$ ). In an carlier press release, however, CORE claimed that the libertarian approach adopted in Ihman Reprodinctive Techmologies and the Law, supra note 12, seems to contradict the tenor of the submissions received in the course of the wide-ranging public consultation undertaken by the Committee, and that it places the British public "dangerously ... between the devil and the deep blue sea" (the "devil" apparently being the unelected HFEA and the "deep blue sea" being the libertarian-leaning Select Committec). See CORE, Press Release, "No to Social Sex Selection, Hybrids, Reproductive Cloning - UK Between the devil and the deep blue sca" (21 March 2005), online: CORE <www.corethics.org/document.asp?id= cpr220305. txt\&se $=2 \& s t=6>$ ). Clearly, CORE is unhappy with the permissive approach adopled by the HFEA and with the libertarian slant adopted in the Committee's Report, and will seemingly only be satisfied when Parliament takes control over the "sensitive ethical issues" involved in this context, and makes decisions on those issues in accordance with CORE's positions (a principal tenet of which is "[a]bsolute respect for the human embryo." See CORE, online: <www.corethics.org/aboutabout.asp>). Caulfield, "Bill C-13," supra note 24 at 23 (note 30); National Health Law and Family Law Sections, Canadian Bar Association. "Submission on Draft Legislation on Assisted Human Reproduction" (2002) 10:2 Health L. Rev. 25 at 27 [CBA Submission].

Supra note 69.

CBA Submission, stupra note 87 at 27.

Don P. Wolf, "An Opinion on Regulating the Assisted Reproductive Technologies" (2003) 20 Journal of Assisted Reproduction \& Genetics 290; Jackson, Regulating Reproduction, supra note 1.

See e.g. Caulfield, "Bill C-13," supra note 24; Caulfield, "Clones, Controversy and Criminal Law;" supra note 24; Harvison Young \& Wasunna, supra note 19; Baylis, supra note 24. 
department) acting aione. A material benefit specifically related to the existence of an independent regulatory agency is its potential role as a focal point for public debate and discussion of the ethical issues to which the use of reproductive technologies give rise. ${ }^{92}$ An especially important advantage of having a regulatory system in place is the ability to collect data about practices. ${ }^{93}$ It can also allow public debate and discussion as part of the policy making process - the only meaningful way for the public to have input into the uses of reproductive technologies is for the public to be aware of current practice. ${ }^{94}$ In addition to being of benefit specifically in relation to ARTs, a regulatory system that focuses some attention on issues in assisted reproduction might also help to bring reproductive healthrelated issues more generally into focus. Reproductive health policy in general would benefit from a considered national approach. ${ }^{95}$

The U.K. experience suggests that public regulation of ARTs can be effectively achieved by way of an independent regulatory agency with a policy making role. In my view this approach to regulation is superior to that outlined in the $A H R$ Act. Admittedly the HFEA itself has been criticized on many fronts and by many players, but as a number of commentators have pointed out, criticism is not surprising given the HFEA's mandate to "[seek] to regulate in an area where people hold strong but incompatible views." the criticism is in any case aimed at the form and content of the HFEA's decisions, rather than at the fact that an unelected body is the entity making these decisions. ${ }^{47}$ In spite of the fact that the HFEA has some very vocal critics, by and large it seems that the U.K.'s ART regulatory system is well regarded. The U.K. system has influenced developments in Australia and France, in addition to having made a significant impression on the Royal Commission. ${ }^{48}$ Most recently, an expert working group made recommendations for regulation of ARTs in the United States that are based on an HFEA-like model."

T. Caullield, L. Knowles \& E.M. Meslin, "Law and policy in the era ol reproductive genetics" (2004) 30 Journal of Medical Ethics 414.

Dala collection is desperatcly needed to permit future research into issues such as the health of of spring conceived using ARTs, as well as family and psychosocial implications raised by the use of reproductive technologies. See e.g. Genetics and Public Policy Center (GPPC), Preimplantation Genetic Diagnosis: A Discussion of Challenges. Concerns and Preliminary Policy. Options Related to she Generic Texting of Human Embryos (Washington, D.C.: Genetics and Public Policy Center, 2004), online: GPPC $<$ htıp://dnapolicy.org/downloads/pdis/policy_pgd.pdis.

lbid.

As I have argued elsewhere, a review of law and policy around reproductive health and reproductive decision making reveals an ad hoc approach to these issues that fails to appropriately protect reproductive autonomy (Erin Nelson," Reproductive Autonomy and the Regulation of Reproduction: Legal and Policy Choices" (December 2004), submitted to the Social Sciences and Humanities Research Council of Canada and the Law Commission of Canada; copy on file with author.)

Angus Dawson, "The Human Fertilisation and Embryology Authority: Evidence Based Policy Formation in a Contested Context" (2004) 12 Health Care Analysis I at 5. Sec also Derek Morgan, "Ethics, Economics and the Exolic: The Early Career of the HIFEA" (2004) 12 Health Care Analysis 7 at 10 and William Leigh Ledger, "Regulation of reproduction in the UK" (2005) 8 Human Fertility 65 at 67. But see supra note 86.

See e.g. Human Reproductive Techologies and the Law: Oral and Writhen Evidence, supra note 79, at Ev 225, Ev 280. Ev 362. Ev 399; and Erik Parens \& Lori P. Knowles, "Reprogenetics and Public Policy: Reflections and Recommendations" (2003) 33:4 Hastings Cir Rpt S3 ["Reprogenetics and Public Policy"].

"Reprogenetics and Public Policy," ibid. at S15-16, S18-21. 
As will be illustrated in the next section, which provides a sort of "case study," the HFEA has proved to be responsive, flexible and willing to modify its approach when warranted. It has been required to deal with complex and ethically challenging issues, has taken its public consultation role seriously ${ }^{100}$ and has fostered a facilitative approach to ART research and practice that has allowed the U.K. to become an international leader in ART-related science. As one fertility expert has said:

[O]verall I would commend the Authority for maintaining an up-to-date, common sense approach to its complex role. It is easy to criticise the HFEA, but the organisation serves to deflect many of the ethical and political difficulties that would otherwise bedevil day-10-day clinical care, to define what may and may not be done, and to act as an interface between a rapacious news media, a concemed public, a reactive and frequently reactionary Parliament and those of us involved in clinical practice in IVF. ${ }^{101}$

I do not mean to suggest that the criticisms aimed at the HFEA are without foundation, nor that they need not be taken seriously. Rather, I seek to point out that there are significant advantages to the regulatory approach adopted in the U.K. that are manifestly absent in the new Canadian legislation. Rather than creating opportunities for meaningful dialogue among the AHRA, Health Canada and Parliament, and for each of those three entities to play an important yet distinct role, I fear that the regulatory structure adopted by Parliament will lead to a re-visiting and rehashing of the "politics of life" that played such a fundamental role in the debate around the legislation itself, and that progress in actually regulating the technologies will therefore prove elusive.

\section{Regulation of Preimplantation Genetic Diagnosis}

In conjunction with this broad overview of the AHRA and its anticipated role, it is helpful to consider a specific example to shed further light on the distinctions between the function of the HFEA and that of the AHRA. Preimplantation genetic diagnosis (PGD) is a good example for a number of reasons. First, PGD is controversial. It is newer among ARTs and, as a result, the social debate remains to a large degree in the initial "resistance" phase of public reaction to such technologies. ${ }^{102}$ While its purpose is to diagnose genetic abnormalities, its use in the very early stage of embryonic development gives rise to concerns that it might also be used in manipulating the genetic blueprint of the embryo - in other words, there is a pervasive fear that PGD will ultimately be used to create "designer babies." ${ }^{103}$ PGD is also used in a context that is undergoing rapid evolution - as new genetic

Some would say too seriously; see e.g., John Harris, "Sex selection and regulated hatred" (2005) 31 Journal of Medical Ethics 291 at 291 and Dawson, supra note 96 at 3. Ledger, supra note 96 at 67.

As Emily Jackson notes, in the years intervening between the birth of Louise Brown and the enactment of the HFE Act, supra note 7, "public perception of infertility treatment had undergone a subtle transformation, from almost universal uneasiness to qualified approval" (Emily Jackson. "Public Opinion and the Regulation of Conception" in W. John Morgan \& Stephen Livingstone, eds., Law and Opinion in Twentieth-Cenury Britain and Ireland (Houndmills. U.K.: Palgrave MacMillan. 2003) 84 at 88).

See c.k., John A. Robertson, "Proereative Liberty and Harm to Offspring in Assisted Reproduclion" (2004) 30 Am. J. L. \& Med. 7 at 35: K.W. Anstey, "Are attempts to have impaired children justifiablc?" (2002) 28 Joumal of Medical Ethics 286 (contemplating a case in which a couple deliberately sought to have a deaf child using antificial insemination); and GPPC, Reproductive Genetic Testing: What America Thinks (Washington. D.C.: Genetics and Public Policy Center, 2004) at 17, online: <hutp:// 
tests are developed for, inter alia, late onset disorders and genetic differences that might or might not be considered "disorders" (for example, short stature), they become available for use in PGD. As such, regulation of PGD demands flexibility and responsiveness from the regulatory regime. It also provides an excellent example of the need for transparency and accountability in any regulatory structure.

The PGD example clearly demonstrates the need for specialized expertise in decision making (based on public input and parliamentary oversight). PGD is also a good example in this comparative look at the HFEA and its Canadian counterpart because the HFEA's handling of the licensing of PGD has raised challenges to the scope of the HFEA's authority that have led to judicial consideration of its enabling statute, specifically with a view to resolving concerns around techniques that were not foreseen at the time the legislation was enacted. In addition, the PGD example illustrates the importance of the authority's willingness to revisit its earlier decisions in light of emerging evidence. Finally, a look at the specifics of regulation of PGD in the Code of Practice sheds light on the intensive, detailoriented nature of the regulatory process more generally. ${ }^{104}$

As the Minister of Health has not yet proposed regulations around PGD, this case study may seem premature. We know that regulation will be forthcoming, but we do not yet know its content; indeed, the content of all of the regulations pursuant to the $A H R A c t^{105}$ remains to be seen. In my view, it is nevertheless useful to consider these issues now, as the process of implementing the legislation gets underway, in the hope that such reflection might engender a brighter future for meaningful ART regulation in Canada.

First, I will examine the specifics of PGD regulation, then turn to the legal and ethical issues that have been raised.

\section{A. UNITED KINGDOM}

What follows is a brief description of regulation of PGD in the U.K. as it has evolved in conjunction with a public consultation process undertaken between 1999 and 2001. ${ }^{106}$

Preimplantation genetic diagnosis is not expressly mentioned in the HFE Act. $^{107}$ The explicit authority to regulate various aspects of PGD arises from ss. 3 and 17 of the $H F E A C t$, as well as Schedule 2, which states that a licence may authorize "practices designed to secure

tools-content.labvelocity.com/pdfs/6/66756.pdp (noting that threc-quarters of survey respondents agreed or strongly agreed that "[t]echnology will inevitably lead to genetic enhancement and designer babics").

Code of Practice, supra note 37. In tum, this raises questions, even for advocates of parliamentary oversight, about Parliament's capacily to regulate in this area on an ongoing basis. Supra note 3. Health Canada published proposed regulations under s. 8 of the Act in Seplember 2005. Sec Assisted Human Reproduction (Section 8) Regulations, C. Gaz. 2005.1.3053.

Human Fertilisation and Embryology Authority \& Advisory Committec on Genetic Testing. "Consultation Document on Preimplantation Genetic Diagnosis" (2000), online: HFEA <www.hfea. gov.uk/AboutHFEA/Consultations/PGD\%20document.pdis: Human Genetics Commission \& Human Fertilisation and Embryology Authority, "Outcome of the Public Consultation on Preimplantation Genctic Diagnosis" (200I) online: HFEA <www.hfea.gov.uk/AboutHIEA/Consultations/PGD\%20 outcome.pdis. 
that embryos are in a suitable condition to be placed in a woman." ${ }^{0 *}$ Section 3 prohibits the creation, storage or use of an embryo except in pursuance of a licence and s. 17 sets out qualifications of persons involved in carrying out the functions authorized in a licence.

As noted earlier, the HFEA is responsible for maintaining a Code of Practice to guide licensees "about the proper conduct of [HFEA-] licensed activities," 109 including the performance of PGD. Part 14 of the most recent version of the Code of Practice deals comprehensively with the practice of PGD in licensed facilities. Broadly, the Code of Practice deals with licensing of preimplantation testing and accreditation of genetics laboratories. Specifically with respect to PGD, the Code provides direction with respect to staff who may be appropriately involved in PGD, genetic consultation, information to be provided to patients and clinical decision making. ${ }^{110}$ The other section of Part 14 concerns issues related to preimplantation genetic screening for aneuploidy. "'

The section of the Code on licensing of preimplantation testing is very clear - a centre wishing to do such testing must be licensed to do so, and may only perform tests for conditions indicated in the annex to its licence or as specifically approved by a licence committee of the HFEA. Should a centre wish to test for a specific condition not appended to its licence, the centre must apply to the HFEA "for each new condition for which they wish to test and for each test that they wish to use."112 Moreover, centres seeking to test a single embryo for multiple conditions or traits must apply to the HFEA with respect to each particular combination of tests they intend to use, even if they are already licensed to utilize each of the tests individually. Finally, the Code states that "[c]entres may not use any information derived from tests on an embryo, or any material removed from it or from the gametes that produced it, to select embryos of a particular sex for social reasons." ${ }^{.113}$

The Code provides that there is to be a multi-disciplinary approach involved in the provision of PGD, and that those seeking treatment are to have access to both clinical geneticists and genetic counsellors. Information to be provided to patients includes explanation as to the process, procedures involved and the risks involved in IVF and PGD, as well as information about the experience of the facility in performing such procedures. Clinics are expected to provide patients with information concerning the following: (i) genetic and clinical aspects of the specific condition for which testing is sought; (ii) the likely impact of the condition on those affected and their families; (iii) availability of treatment and social support; and (iv) "[w]here the family has no direct experience of the condition, the testimony of families and individuals about the full range of their experiences of living with the condition."14 Finally, the potential outcomes and implications of genetic testing are to be explored with persons seeking treatment prior to PGD being undertaken.

Ibid., Sch. 2 at para. $I(1)(d)$. This schedulc outlines the treatment and research activities for which licences may be granted.

100 Code of Practice, stupra note 37 at 9.

I10 Ibid. at paras. 14.12-14.23.

III Ibid. at paras. 14.24-14.27.

II: $\quad$ bid. at para. 14.7 .

113 Ibid. at para. 14.10. Unlike in the Canadian context, the prohibition on sex selection for non-medical reasons arises from the HFEA's own policy, not from the enabling legislation.

$114 \quad$ Ibid. at para. 14.17. 
While the practice of PGD is comprehensively regulated, there is no list of specific conditions for which such testing may be done, nor is there a list of excluded conditions. Instead, a number of factors are taken into consideration in deciding whether a particular use of PGD is acceptable. Section 13 of the HFE Act requires the consideration of the "welfare of any child who may be borm as a result of ... treatment ... and of any other child who might be affected by the birth,"115 prior to the provision of treatment services. The Code of Practice envisions that this condition will be met on the basis of taking into account the "unique circumstances" of the person(s) seeking treatment, "rather than the fact that they carry a particular genetic condition." 116 The Code does state, however, that PGD is to be used for indications consistent with current practice in prenatal diagnosis (PND), and that it is only to be used where there is a "significant risk of a serious genetic condition being present in the embryo." 117 The seriousness of the condition is not to be determined solely on the basis of clinicians' opinions, but is to be a "matter for discussion between the people seeking treatment and the clinical team." 118 Further, the presence of a significant risk is to be considered in light of the "perception of the level of risk by those secking treatment." 11 " Finally, the Code details a number of factors which are to be considered in the context of decisions about the appropriateness of PGD in any particular case. These factors are tailored to the needs and interests of those seeking treatment, and include their views of the condition sought to be avoided by testing, their previous reproductive experience, the likely degree of suffering associated with the condition, the availability of therapy, now and in the future, and the extent of social and family support available. ${ }^{120}$ In January 2005 , the HFEA announced a new policy "to streamline the approval" of applications for PGD licences. Applications by clinics with "proven expertise in performing embryo biopsies" for licences to carry out previously approved uses of PGD will be "fast-tracked."121

Although PGD is closely regulated by the HFEA, it is generally available in the U.K. for the same conditions as PND. Rather than being controlled by way of prohibitions (other than in the case of sex selection for non-medical reasons), it is made available under the auspices of a permissive licensing regime, with decision making to take place after consideration of factors that the HFEA, following a public consultation, has deemed relevant.

Perhaps not surprisingly, given the polarized nature of the public debate around genetic and reproductive technologies, there remain some contentious issues around the use of PGD,

\footnotetext{
11 HFE ACt, supra note 7, s. 13(5). Sec Code of Practice, supra note 37.

116 Code of Practice, ibid. at para. 14.20.

II: $\quad$ lbid. at para. 14.22 .

118 bid.

119 Ibid.

120 Ibid. at para. 14.23.

121 Human Fertilisation and Embryology $\Lambda$ uthority, Press Release: "HFE $\Lambda$ announces new process to speed up applications for cmbryo screening" (19 January 2005), online: HFEA <www.hfea,gov,uk PressOflice/Archive/1106139513>. Requests for licences for "less common specialised applications" of the technique will require full review by an HFEA licence committee on an individual basis. The specialized applications referred to include new conditions, late-onset or susceptibilty testing, and HLAtissue typing, either alone or in conjunction with PGD (see also Mohammed Taranissi \& James Law ford Davies, "Why treat PGD for late onset disorders differently?" BioNew's (4 May 2005), online: $<w w w$, bionews.org.uk/commentary.lasso'?storyid=2550>).
} 
in particular, the use of PGD for sex selection for non-medical reasons, ${ }^{122}$ and the use of testing to create so-called "saviour siblings" (embryos that are tissue-matched to a sibling with a serious disease in the hope that IVF will result in the birth of a child who can then donate stem cells from umbilical cord blood to the ill sibling). Other controversial applications of PGD include testing for late-onset conditions (such as Huntington Disease), susceptibility testing (for example, breast and colon cancer) and testing for carrier status. ${ }^{123}$

The use of tissue matching in PGD is the subject of very recent controversy in the U.K., which has been helped along by innumerable media reports of the HFEA's stance on this issue and its effects on specific families. In late 2001, the HFEA announced its decision to permit HLA-typing to be used in conjunction with PGD for serious genetic disease. ${ }^{124}$ In early 2002, the HFEA granted a licence to a Nottingham hospital to perform PGD and tissue typing as part of the IVF treatment for the parents of a child suffering from B-thalassemia, a rare and potentially fatal genetic blood disorder. The parents hoped that they would ultimately bear a child whose umbilical cord blood could provide a tissue-rnatched source of stem cells as a cure for their son. ${ }^{125}$ The grant of this licence itself caused concern on the part of some pro-life organizations such as Comment on Reproductive Ethics (CORE), which

12: Sex selection has been the topic of a fairly recent HFEA report. Though the repurt's focus was on unregulated sperm sorting techniques, PGD was also addressed bricfly. The repon concludes that PGD should be available to those at risk of passing on a serious genetic condition to their offspring, that it should be closely regulated and that, while it can be used to avoid the transmission of sex-linked conditions, its use should be reserved for genuinely serious cases involving medical reasons, See Human Fertilisation and Embryology Authority, Sex selection: Options for Regulation: A reporr on she HFEA 's 2002-2003 review of sex selection including a discussion of legislative and regulatory options (London: HFLA. 2003) at paras. 99.102. Sex sclection for social purposes was also considered in Human Reproductive Technologies and the Lonw, supra note 12, and the Committec concluded at 64 that

[t] the onus should be on those who oppose sex selection for social reasons using PGD to show harm from its use.... [T]he use and destruction of embryos does raise ethical issues and there are grounds for caution. The issue requires greater analysis than has been afforded it by the HFEA and we urge greater efforts to establish the demographic impacts ... and the implications for the creation and destruction of embryos in vitro before new legislation is introduced. On balance we find no adequate justification for prohibiting the use of sex selection for family balancing.

The Ethics and Law Committec of the HFEA initiated a policy review in 2005 to consider all of these potential applications of PGD in order to facilitate decision making by licencing comniltees. See Human Fertilisation and Embryology Authority, Ethics and Law Committec, "Emerging issues in PGD: project initiation document" (April 2005), online: HFEA <www,hfea.gov.uk/AboutHFEA/Committees/ EthicsandLawCommittee/2005April/2005-04-14\%20Committec\%20LLC\%20paps.r\%20\%2804-05\% $29 \% 2001 \% 20-\% 20$ Annex\%20A.pdi>. The HFEA recently released its report on the use of PGD to test for lower penetrance, late-onsel conditions such as inherited breast, bowel and ovarian cancer. The HFEA has decided to consider the use of PGD for these conditions on a case-by-cast: basis. See HFEA, Choices \& boundaries reporı (London: HFEA, 2006), onlinc: HFEA <www.hfea.gov.uk/ AboutHFEA/HFEAPolicy/Choicesandboundaries/Reportonthepublicdiscussion/Choices\%20and\%20 boundaries\%20repor1\%202006\%20FINAL.pdis.

Human Fertilisation and Embryology Authority, Press Release, "HFEA to allow tissue typing in conjunction with preimplantation genetic diagnosis" (13 December 2001), online: HFEA <www.hfea. gov.uk/PressOffice/Archive/HFEAtoallowtissuetypinginconjuntionwithpreimplantation geneticdiagnosis>.

123 Roger Hlighficld, "Third time lucky lor Zain, his parents pray" The Telegraph (17 May 2003), online: news.lelegraph <www.lelegraph.co.uk/news/main.jhtml? xml=\%2Fnews\%2F 2003\%2F05\% 2F17\%2Fnfert17.xml>; Colin Gavaghan, "Pro-life" tactics on tissue typing" BioNenur ( 15 April 2003). online: <www.bionews. org.uk/commentary.lasso?storyid=1642>; and "Hashmis fail in 'saviour sibling' attempt" BioNens (9 July 2004), online: <www.bionews.org.uk/new.lasso?storyid=2180>. 
went on to challenge the licence in the English courts. ${ }^{126}$ The objection raised by CORE was based on its concerns around the very idea of embryo selection (and the corollary of selection, which is that some embryos will be discarded) and its assertion that the contentious ethical issues raised by this use of reproductive technology demand parliamentary oversight. $^{127}$ The legal dimension to the group's argument centred on the claim that the HFEA did not have the legislative authority 10 grant a licence permitting PGD and tissue typing. ${ }^{128}$

The legal claim centred on a question of statutory interpretation: are PGD and tissue typing authorized by the HFE Acr? More specifically, can PGD and tissue typing be considered activities which are "necessary or desirable for the purpose of providing treatment services,"129 and do these techniques and their proposed use in this case amount to "practices designed to ensure that embryos are in a suitable condition to be placed in a woman or to determine whether embryos are suitable for that purpose"? ${ }^{130}$ The CORE application was successful at first instance, where Maurice Kay J. refused to conclude that ensuring tissue compatibility with an older sibling could be said to be "'necessary or desirable' for the purpose of assisting a woman to carry a child," 31 as tissue typing would have no effect on the ability of a woman to carry the embryo afler implantation.

The Court of Appeal and the House of Lords gave much broader reading to the relevant statutory language and concluded that the $A c t$ indeed authorizes the HFEA to license PGD and tissue typing. In a judgment that implicitly recognizes a wide scope for autonomous reproductive decision making, the House of Lords acknowledged that its reading of "suitability" of an embryo for implantation in a woman would conceivably

include activities highly unlikely to be acceptable to majority public opinion... The fact that these decisions might raise difficult ethical questions is no objection. The membership of the [HFE $A$ ] and the proposals of the Wamock Commitlee and the While Paper make it clear that it was intended to grapple with such issues. $^{132}$

136. Quintavalle (on behalf of Comment on Reproductive Ethics) v. Human Fertilisation and Embnology Authority (Secretany of State for Health intervening), (2003). [2004] Q.13. 168, 2003 EWCA Civ 667. aff Q Quintavalle, H.L., supra note 86.

12. Committee on Reproductive Ethics, Press Release, "CORE wins judicial review against the HFEA" (20 December 2002), online: CORE <www.corethics.org/document.asp?id $=$ cpr201 202.txt\&se $=2 \& s t=6>$. $R$ (on the application of Quintavalle) v. Human Fertilisation and Embryology Authority. [2003] 2 All E.R. 105, 2002 EWHC 2785 (Admin) [2002 Quintavalle Admin].

139 HFE Act, supra note 7, Sch. 2 at para. I(3).

130. Jbid. at para. l(1)(d).

1312002 Quintavalle Admin, supra note 128 at para. 17.

112 Stupra note 86 at para. 26, per Hoffman L.J. In a separate concurring judgment. Brown L.J. of Eatonunder-Heywood stales (at para. 62) that, once it is conceded that PGD is licensable for the purpose of producing a genetically healthy child,

there can be no logical basis for construing the authority's power to end at that point. PGD with a view to producing a health child assists a woman to carry a child only in the sense that it helps her decide whether the embryo is "suitable" and whether she will bear the child. Whereas, however, suitability is for the woman, the limits of permissible embryo selection are for the authority. In the unlikely cvent that the authority were to propose licensing genetic selection for purely social reasons, Parliament would surcly act at once to remove that possibility. 
What caused more concern to some observers than the grant of this licence was the HFEA's decision in 2002 to deny a licence to another set of parents wishing to use P'GD and tissue typing. The parents sought to conceive a child that could donate umbilical cord blood to their son, who suffers from Diamond-Blackfan anaemia (DBA), a rare blood disease that results from a sporadic genetic mutation. ${ }^{133}$ Because the intended child would not be at risk of DBA, the procedure would have no conceivable benefit to him or her; the only potential beneficiary of the procedure would have been the ill sibling. The HFEA refused to grant a licence in this case on the basis that PGD was not needed in order to prevent the transmission of a serious genetic condition to the potential child and that the procedure would involve some risk (and no corresponding benefit) to the child. ${ }^{134}$ Arguably, as others have noted, the HFEA's decision to refuse a licence in this case rests on a "distinction without a difference" and seems to have been made on the basis of speculation as to potential harm rather than on the basis of evidence. ${ }^{135}$

Since the 2002 refusal, the HFEA has had the opportunity to reconsider and reverse its position on permitting PGD and tissue typing in such cases. After issuing its revised policy on tissue typing in July 2004, the HFEA granted a licence to another couple whose son also suffers from DBA. In a press release dated 21 July 2004, the HFEA states that it has "now carefully reviewed the medical, psychological and emotional implications for children and their families as well as the safety of this technique. There have been three further years during which successful embryo biopsies have been carried out ... and we're not aware of any evidence of increased risk." 136

Returning for a moment to the question of the appropriate oversight entity, it is instructive to note that critics on both sides of the tissue typing issue would argue that the HFEA went wrong here. Those who oppose any embryo selection will clearly not be satisfied by the HFEA's extension of the circumstances in which tissue typing may be licensed, and those who would like to see a more liberal approach on the part of the HFEA have criticized the original position taken by the HFEA on this matter. ${ }^{137}$ Some of those critics, such as CORE and like organizations, as well as the Select Committee on Science and Technology, would argue that the HFEA's missteps and the related ethical concerns, indicate the need for parliamentary oversight. ${ }^{138}$ But why should we assume that Parliament would have made the decision any differently? Or that Members of Parliament would be as willing to revisit the

Sally Sheldon \& Stephen Wilkinson. "'Saviour Siblings': Hashmi and Whitaker. An Unjustifiable and Misguided Distinction," online: ProChoice Forum <www,prochoiceforum.org.uk/irl_rep_tech_2.asp>; Juliet Tizzard, "Why is PGD for tissue typing only not allowed?" BioNews (5 August 2002), online: <www.bionews.org.uk/commentary.lasso?storyid=1329> [Tizzard, "PGD for tissue typing"]. The couple ultimately travelled to the U.S. to have the procedure done and had a son who tumed out to be a perfect tissue match for his older brother. "Designer baby transplant success" $E B C$ News (27 July 2004), online: <ht1p:/news.bbe.co.uk/2/hi/health/3930927.stm>. Juliet Tizzard, "'Saviour siblings': a child to save a child," online: Cardiff Centre for Ethics, Law and Society <www.ccels.cardiff.ac.uk/issue/tizzard.html>. Human Fertilisation and Embryology Authority, Press Release, "HFEA agrees to extend policy on tissue typing" (21 July 2004), onlinc: HFEA <www.hfea.gov.uk/PressOffice/Archive/1050427358>. Human Reproductive Technologics und the Low, supra note 12 at para. 251, where the Committe states that "It he development of HFEA's policy and licensing decisions on preimplantation tissue typing has been highly unsatisfactory." 
initial decision to refuse tissue typing not in conjunction with PGD for an inherited abnormality? Or, for that matter, that Parliament could have come to a consensus at all, given the deep divisions that appeared among members of the Select Committee on Science and Technology. ${ }^{139}$ Even the argument that a process involving parliamentary oversight would be more public-oriented and more accountable is not particularly persuasive; an independent regulator such as the HFEA (or the AHRA) could be required to consult the public on issues such as these. Indeed, even the House of Commons Select Committee has been accused of disregarding evidence received during its public consultation. ${ }^{\text {to }}$

In any event, the HFE Act is in line for reform in the near future. By April 2008, the HFEA and the Human Tissue Authority (HTA) will be replaced with the Regulatory Authority for Tissue and Embryos (RATE), which will be responsible for all human tissues and cells. ${ }^{\mid+1}$

\section{B. CANAdA}

As noted earlier, although the political discussion around regulating reproductive technologies in Canada has been ongoing since the Royal Commission's final report in $1993{ }^{142}$ Canada's regulatory approach is in its infancy. And, while a number of groups in Canada have studied regulation of reproductive and genetic technologies, ${ }^{143}$ it bears mention that PGD has not been the subject of meaningful public consultation in Canada. PGD was not used in humans until $19899^{14+}$ it therefore did not become a particularly significant issue for these various commissions, whose mandates either antedated or overlapped with the development of PGD. Even to the extent that public attitudes respecting the use of PGD were canvassed, however, the findings are now so dated as to be unlikely to represent current sentiment.

The $A H R A{ }^{145}$ does not mention PGD specifically, but indirectly regulates some aspects of PGD. Following the advice of the Royal Commission, the use of PGD for sex selection for social purposes (including family balancing purposes) is prohibited by the Canadian legislation. ${ }^{146}$ In addition, PGD will ultimately be governed by the AHRA on the basis of regulations dealing with the collection, alteration, manipulation or treatment of any human reproductive material for the purpose of creating an embryo, ${ }^{147}$ the offer of counselling for individuals undertaking assisted human reproduction activities, ${ }^{148}$ and the storage, handling

See supra note 76.

See Eighth Report, supra note 76. Interestingly, in the Committee report itself, the authors nole the potential pitfalls in undertaking public consultations (see Eighh Report, ibid. at para. 361).

The change will require the adoption ol new primary legislation, which certainly implies that the $H F E$ Act will be modified. The Department of Health issucd its consultation document in August 2005 (United Kingdom. Department of Health, Revie'w of the Human Fertilisation and Embryologv Act: A Public Consultation (London: Department of Ilealth. 2005), online: Department of Health <ww'w. dh.gov.uk/assetRoov/04/1 1/78/72/041 1 7872.pdt>).

Proceed Wish Care, supra note 11.

Ontario Law Reform Commission, supra note 11; Law Reform Commission of Canada, supra nole 11. Handyside et al., supro note 9.

Supra note 3.

See Proceed with Care, supra note 11 at 907. Recommendation 265.

AHR ACT, supra note 3, ss. 10(1), 10(2).

Ibid., s. 14(2)(b). 
and use of reproductive materials and embryos. ${ }^{149}$ The precise content of such regulations will not be known until after the AHRA has been established and the government has turned its attention to the ambit of the regulations. In general, the Agency will be empowered to regulate assisted reproductive techniques used both in the clinical and research settings, including PGD, in a comprehensive way. The current regulatory picture involves some regulation of assisted reproduction, but regulation is neither comprehensive nor integrated, nor is it uniformly applied or enforced. ${ }^{150}$ In that respect at least, the AHRA will play a welcome role in clarifying the current fragmented approach to regulation of PGD.

Currently, standards that might touch on aspects of PGD are found in several statutes, including the federal Food and Drugs $A c t ;{ }^{151}$ the Quebec $A c t$ respecting medical laboratories, organ, tissue, gamete and embryo conservation and the disposal of human bodies (which regulates "gametes or embryo conservation centres," centres that collect, conserve or distribute human gametes with a view to using them in medical or scientific procedures); $i^{152}$ and possibly provincial human tissue legislation. ${ }^{153}$ Additionally, there are professional guidelines and policies in place to help guide medical practice involving some aspects of assisted human reproduction. In particular, the Society of Obstetricians and Gynaecologists of Canada and the Canadian Fertility and Andrology Society have produced a joint policy statement on PGD. ${ }^{15+}$ The policy statement, drafted in 1999, treats PGD as a form of research (as opposed to a therapeutic intervention) and states that while PGD "is morally acceptable to diagnose severe genetic disorders[, it] should not be used to diagnose benign disorders." 155 Further, the policy statement asserts that the use of PGD for nonmedical sex selection is morally unacceptable, that "PGD should only be available in the context of structured clinical trials approved and monitored by research ethics boards," 156 and that it should not be used to promote discrimination or "eugenic practices."157 Finally, insofar as PGD is used in research applications, it would be governed by the Tri-Cotmcil Policy

1s4 Ibid., s. 10(3).

190 Roxanne Mykitiuk \& Albert Wallrap, "Regulating Reproductive Technologies in Canada" in Jocelyn Downic, Timothy Caulfield \& Colleen M. Flood, eds., Cunadian Healsh Law and Policy, $2 d$ ed. (Toronto: Butterworths, 2002) 367 at 378-81.

151 R.S.C. 1985, c. F-27. The Food and Drugs Act deals with processing, testing and distribution of semen for donor insemination (Processing and Distribution of Semen for Assisted Conception Regulations, S.O.R./1996-254, as am.).

192 R.S.Q., c. L-0.2. Section l(m.1) delines "gametes or embryos conservation centre," but this subsection is not currently in force.

153 For example. IHuman Tissuc Gifi Aci, R.S.A. 2000, c. 11-15. A tew such statules, although they generally deal with organ transplantation, do not define "tissue" namowly, and therefore could be involved in the regulation of some aspects of ARTs (see e.g., Human Tissue Act, R.S.N.W.T. 1988, c. H-6.) "Policy Stutement: Ethical Issues in Assisted Reproduction: Pre-implantaion Genctic Diagnosis" (1999) 21 Joumal SOGC: Joumal of the Society of Obstetricians and Gynaecologists of Canada 372.

iss Ibid. at 374.

156 Tid.

157 Ibid. 
Statement: Ethical Conduct for Research Involving Humans, ${ }^{158}$ which has rules in place as to ethically appropriate uses of human tissue, gametes and embryos. ${ }^{159}$

Certainly, the establishment of the AHRA will afford the opportunity to integrate all of these various aspects of assisted human reproductive techniques, of which PGD is one example, into a comprehensive regulatory framework as has been done in the U.K. It is troubling, though, to recognize that in light of the role and structure of the AHRA, there is a real chance that all of the controversial political issues around PGD in particular will do nothing more than provide an opportunity for revisiting ground already covered in the debate and passage of the $A H R$ Act itself.

\section{CONCLUSION}

In the three decades during which assisted reproductive technologies have become a fixture of the societal landscape, one thing has become very clear: reproductive technologies and their potential uses are controversial. This truism applies not only to fears around uses or misuses of ARTs, but to attempts to regulate them as well. A regulatory system such as that found in the U.K. (or as is poised to be put in place in Canada) will certainly not satisfy all participants in the debate over appropriate forms of regulation, but comprehensive regulation by an independent agency should certainly not be dismissed as an alternative due to fears that such a system might dampen research and practice involving reproductive technologies. Canada, like the U.S., has had, to date, a complex web of regulatory approaches for reproductive technologies and both countries have lacked a central "oversight" agency, but the practices in the two nations have developed very differently. There is much more work being done in the reproductive medicine arena in the U.S. than in Canada, and this is particularly the case with respect to PGD. Unlike Canada and the U.S., the U.K. has had a comprehensive system of regulation for some time, and has nevertheless remained on the leading edge of research and practice in reproductive technologies. Indeed, the U.K. has recently become the first jurisdiction to permit scientists to attempt to isolate stem cells from cloned early human embryos, thus attesting to the fact that the existence of a coherent regulatory scheme need not be viewed solely as a barrier to progress. ${ }^{160}$

As I hope to have shown in this article, a significant problem with ART regulation in Canada is related to the structure and role of the AHRA; in particular, its lack of a role in making policy around appropriate applications of these technologies. The $A H R A C$ seems to envision the formation of an expert body that will have very little need for expertise, given that it will apparently be given policy directions by the Minister of Health. Further, the Board

Canadian Institutes of Health Research. Natural Sciences and Engincering Research Council of Canada \& Social Sciences and Humanities Research Council of Canada, Tri-Council Policy Statement: Lithical Conduct for Research Involving Jlumans (Ottawa: Public Works and Government Services Canada. 1998), online: Covernment of Canada <www.pre.cthies.ge.ca/english/policystatement/policy statement. cfm $>$ [updated October 2005). 
of Directors of the AHRA, for which the government began recruiting in $2005,{ }^{161}$ will have no involvement in the ongoing process of crafting the regulations that will underpin its dayto-day operations and determine how complex ethical issues are to be resolved. And, finally, the nature and degree of parliamentary review of ART policy contemplated by the $A H R A C t$ creates an unnecessarily inefficient and cumbersome process.

While the HFEA is not without flaws, it has a substantial advantage over the soon-to-exist AHRA in that it is clearly expected to (and does) take an active role in policy making around reproductive technologies and their acceptable uses. This ensures that policy decisions can be made on the basis of expertise, that regulation can be flexible and responsive and that, perhaps most importantly, Parliament need not spend yet more time and energy debating unresolvable issues related to the status of embryonic life.

Io1 See Health Canada, online: <www.hc-se.gc.ca/hl-vs/reprod/agenc/recruitment-recrutement/index ce. $h \mid \mathrm{ml}>$. 